\title{
Adaptation to climate change in the insurance sector: examples from the UK, Germany and the Netherlands
}

\author{
E. Carina H. Keskitalo • Gregor Vulturius • Peter Scholten
}

Received: 15 March 2012/ Accepted: 25 October 2013/Published online: 8 November 2013

(C) The Author(s) 2013. This article is published with open access at Springerlink.com

\begin{abstract}
Adaptation to climate change, particularly flood risks, may come to pose large challenges in the future and will require cooperation among a range of stakeholders. However, there presently exists little research especially on the integration of the private sector in adaptation. In particular, recently developed state programs for adaptation have so far been focused on the public sector. Insurance providers may have much to contribute as they offer other parts of society services to appropriately identify, assess and reduce the financial impacts of climate change-induced risks. This study aims to explore how the institutional distribution of responsibility for flood risk is being renegotiated within the UK, Germany and Netherlands. Examining how the insurance industry and the public sector can coordinate their actions to promote climate change adaptation, the study discusses how layered natural hazard insurance systems may result from attempts to deal with increasing risks due to increasing incidences of extreme events and climate change. It illustrates that concerns over the risks from extreme natural events have prompted re-assessments of the current systems, with insurance requiring long-term legislative frameworks that defines the objectives and responsibilities of insurers and the different political authorities.
\end{abstract}

Keywords Climate change · Adaptation · Insurance · The UK · Germany · The Netherlands

\section{Introduction and aim}

As mitigation-the reduction in emissions-will not be sufficient to hinder the climate change caused by currently and previously emitted greenhouse gases (GHG), the expected scale of that change will pose major challenges for adaptation throughout Europe (IPCC 2007). Flooding has often been singled out as a climate risk due to its large impact on

E. C. H. Keskitalo $(\bowtie) \cdot$ G. Vulturius · P. Scholten

Department of Geography and Economic History, Umeå University, 90187 Umeå, Sweden

e-mail: Carina.Keskitalo@geography.umu.se 
infrastructure. Depending on future socioeconomic development and future GHG emissions, it is predicted that climate change may as much as double damage from river floods, with costs reaching $€ 20$ billion between 2011 and 2020 (Feyen and Watkiss 2011). These vulnerabilities correlate with increased infrastructure development in lowland areas as a result of urbanization, among other trends (Aerts and Botzen 2011; Kreibich et al. 2005). Adaptations to flood risks will require coordination among a range of different stakeholders including government—-through planners at several levels—and industry. However, little research has been done to date on integrating the private sector in adaptation, for the recently developed state programs for adaptation have so far focused on the public sector (Smit and Wandel 2006; IPCC 2007; Keskitalo 2010).

The insurance sector constitutes a particularly important case as it offers other parts of society a service for appropriately identifying, assessing and covering climate changeinduced risks: It forms part of a "broader public-private patchwork for spreading risks across time, over large geographical areas, and among diverse social and commercial communicates" (Mills 2005, 1040). While the commercial insurance industry has been one of the first in the private sector to discuss adaptation to climate change (see, e.g., Munich 1973), risk analysis and underlying loss reduction strategies need to be improved to take into account the estimated frequency of extreme weather events and higher risks. Such strategies may include both responses to short-term variations in weather (events) and to long-term trends. As a result of especially large flood events, several countries have started re-assessing the role of commercial insurance and the distribution of responsibility for risk between the public and private sectors. The UK, Germany and the Netherlands are all countries with large flood risks in certain areas, and where the role of public and private actors is being reassessed. The solutions being examined vary from private flood risk insurance in the UK and Germany to public insurance in the Netherlands.

This study aims to explore how the institutional distribution of responsibility for flood risk is being renegotiated in the three countries. The focal question is, to what extent do flood events, or awareness of higher flood risks, influence changes in the distribution of responsibility for costs from flooding between public authorities and the private insurance sector? To address this issue, the study examines how the commercial insurance industry and public authorities can coordinate their actions to promote climate change adaptation.

\section{Theoretical framework}

Adaptation to climate change is defined as the actions taken to respond in different ways to climate change impacts; these include a wide range of responses, such as autonomous actions in reaction to an event such as a flood or planned adaptations that set in place policies and response systems, often as part of a crisis response system (Smit and Wandel 2006). Adaptation commonly requires the coordination of actors across sectors and in particular benefits from actions that institutionalize ways to limit risks to people and property.

Previous studies have highlighted the capabilities of the private insurance industry to assist governmental authorities in helping societies adapt societies to the impacts of climate change (Mills 2009). The industry's "core" business activities, risk transfer, risk assessment and incentivizing risk-reducing activities have been underlined as key factors in this respect (Mills 2005). Potential climate change-induced alterations in the return period of low probability, extreme events and the persistent scientific uncertainty that surrounds them make the insurance industry itself vulnerable through increased damage to its policy 
holders and losses of its own assets (Dlugolecki 2008; Maynard 2008). In order to assess the existing and potential future role of the commercial insurance industry in climate change adaptation, one needs to take into account regulatory frameworks that determine public disaster aid, the pricing of insurance premiums and the distribution of political authority in managing natural risk.

Risk transfer refers to a process where parties such as households or larger social entities shift the financial consequences of retained natural risks to the insurance industry. Natural risk transfer solutions are institutionalized in natural hazard insurance systems that differ among European countries in terms of market regulation and practices of state disaster aid payout (Schwarze et al. 2011). The most common arrangements are fully privatized insurance markets (the UK, Germany, and Sweden) and compulsory coverage of natural hazards in private insurance backed by state support (France and Belgium) (Schwarze et al. 2011; Thieken et al. 2006).

It has been suggested that insurance systems for coping with climate change might adopt a tripartite model: relatively small losses would be absorbed by households and companies; medium-sized damage would be covered by private insurance sectors; and large losses would be covered by the government (Table 1). However, at present, national insurance systems vary in their distribution of financial responsibility, with some dictating public or compulsory insurance for natural hazards, while others only mandate that natural hazards are part of private homeowner insurance. Both of these tend to be financed through public reinsurance. A common solution in Europe is free-market natural hazard insurance, although major losses due to extreme events are often covered by government as an "insurer of last resort," either ad hoc or through specific tax-funded hazard funds (Schwarze et al. 2011; Aakre and Rübbelke 2010; see also Kunreuther 2006). However, downsides to governmental disaster assistance include that it may differ between events (e.g., depending on extent and media coverage) and thereby limiting foreseeability for individuals affected (Thieken et al. 2006; Aerts and Botzen 2011; Botzen and van der Bergh 2012). In the case of a market-based voluntary insurance system, a number of scholars have argued that extensive and unconditional governmental disaster relief may be a disincentive to the purchase of insurance coverage against natural hazards and other private preventive measures (Schwarze and Wagner 2004a, b; Anderson 2000; Aerts and Botzen 2011; Botzen et al. 2009).

The design of such layered schemes, however, may result in the need for complex tradeoffs between actors and the development of systems to distribute responsibility and incentivize protection (Aerts and Botzen 2011). For instance, due to problems of assessing and updating probability estimations of extreme events "[i]t is extremely difficult to insure in a changing environment" (Charpentier 2008, 91). As a result, it can be expected that the means by which the public sector and the private insurance sector adapt to climate change may not yet be entirely developed. The public and private sectors may both at present be adjusting, without clear systems or steering mechanisms in place for adaptation. Adaptation and adaptation strategies may be developing over time in ways that involve changing

Table 1 A multilayered insurance program (reproduced from Botzen et al. 2010)

\begin{abstract}
Layer 3
Layer 2
\end{abstract}

Layer 1
Government

Capital markets

Reinsurance companies

Primary insurance companies Households and companies 
institutional cultures with regard to probability-based risk assessment (from backcasting to proactive assessment of future risks) and promotion and coordination of risk mitigation among and with governmental authorities and policy holders.

In general, however, commercial insurance companies already employ a number of strategies that could potentially serve adaptive capacity building against climate change impacts among the companies themselves as well as other societal actors. For example, insurance businesses manage the extent of loss compensation by spreading and segregating risks (e.g., discriminating between different insurance policy holders depending on risk exposure), incentivizing preventive measures and monitoring (for instance, rewarding risklimiting behaviors among customers) or bundling different hazards into multiple-risk insurance schemes (such as general home insurance or elementary loss insurance). Risk and damage quantification and prediction are the central premise that underpins adaptive actions taken by insurers to address climate change impacts. Risk can only be regarded as insurable if the probability and extent of losses under different levels of coverage can be assessed, and if knowledge and governmental regulations allow differential premiums depending on exposure, for instance to encourage policy holders to avoid building or residing in low-lying areas (Botzen and van der Bergh 2008). ${ }^{1}$ Of particular importance for this paper is the fact that the ability or inability to acquire a certain type of insurance coverage, such as natural hazard insurance, may determine the location of economic and social activities. (F\&C Management 2007).

For the insurance industry, climate change represents an emerging risk, that is, a new risk that affects insurance premiums that have already been set without appropriate prior risk assessment (UNEP 2009). Commercial insurers have a number of options to address climate change: They may limit risk (set limits restricting payouts, withdrawing or limiting coverage), diversify risks (operate in different insurance branches or geographical areas), adjust premiums (use risk-differentiated pricing), control damage (limit losses by supporting societal adaptation, e.g., rewarding lower risk with lower premiums) or transfer risk (reinsurance, catastrophe bonds) (Botzen et al. 2010). To do this, however, Mills notes that "a more diverse set of industry actors (agents, brokers, underwriters, risk managers, trade associations, executives) must be educated and involved in assessing and implementing the opportunities" (Mills 2003, 275). In addition, Mills points out that problems exist in that insurers' weather-related models (e.g., catastrophe models) focus mainly on extreme events (rather than including the sum of smaller events), build on historical trends and are not easily integrated with the future-focused climate change models (which may also not be easily applied to decision making in industry) (Mills 2005). Information and knowledge systems thus need to better be able to represent risk. As a result, LeBlanc and Linkin (2010) note that potential ways of adapting within the insurance industry may include increased focus on GIS (geographical information systems) to pinpoint risks, disaster preparedness and recovery plans, and participation in building code development (including training for code-inspection officials). Insurers also need to provide educational information to customers, for instance, on ways of developing private precautionary measures such as flood protection, and to support government adaptation efforts (LeBlanc and Linkin 2010; Kreibich et al. 2005).

While all of these factors will be adjusted to the particular distribution of hazard coverage between public and private actors in any given case, interaction between public and private systems is crucial, with regard to both interaction between these sectors and presenting coherent information to the public. For instance, "in order to minimize the

1 Risks are thus reduced in practice if incentives for risk reduction are provided for instance through riskbased premiums that may affect individual choices (e.g., Botzen et al. 2009). 
damage potential in flood-prone areas, the planning authorities and insurance companies should intensify their interaction with each other in the decision-making process of legally binding development plans" (Petrow et al. 2006, 718). Regulatory frameworks and actions by public authorities are critical to understanding the potential of private insurance companies to absorb residual risks and contribute to risk mitigation. With reference to the potential increase in the number and intensity of extreme events, Herweijer et al. (2009a, b) conclude that insurers are likely to face greater regulative scrutiny if they do not adequately respond to the threat of insurability of certain environmental risks. LeBlanc and Linkin note that given limited information for private insurers on which premiums to raise today with regard to future climate change, proactive measures need to be developed by local and national governments. Government could for instance develop stricter construction standards, include climate change risks in planning (e.g., zoning restrictions) and fund observation, data collection systems and research as well as tools to translate these for industry climate change risk assessment (LeBlanc and Linkin 2010). Government can also help overcome misaligned or missing markets (stimulate insurance, e.g., in underrepresented groups) (Aakre and Rübbelke 2010). Finally, public authorities and the private insurance sector could also work together with the building industry in the development of specific building regulations on which insurance coverage can be based.

\section{Case studies and method}

To study the way in which insurance industries can be integrated in adaptation in different countries, this study reviews the situation in the UK, Germany and the Netherlands, all of which include areas with potentially high flood risks. One-sixth of homes in the UK lie in areas with a high flood risk; flood damages are expected to rise as much as threefold over the next 100 years in Germany; and $70 \%$ of properties in the Netherlands lie below sea or other water levels (ABI 2010; GDV 2011; Botzen et al. 2010). The selection of the UK, Germany and the Netherlands in this study has been undertaken to include the variation between public (the Netherlands) and private (the UK, Germany) insurance systems, all of which are further described in the start of each section. Various systems have previously been described mainly in national contexts (for instance, Thieken et al. 2006; Aerts and Botzen 2011) and compared mainly in reviews for domestic literature (e.g., Vetters and Prettenhaler 2003) (cf. Thieken et al. 2006). An international review is found in von Ungern-Sternberg (2004), although it is not focused per se on responses to climate change.

The study is based on a review of documents (mainly policy reports and literature) that deals with insurance in each country with a focus on the government-industry relationship. The study is further based on semi-structured interviews, undertaken to capture the current situation in the three countries. Interviewee selection aimed to cover representatives of the national, commercial insurance industry in all three countries, as well as governmental authorities charged with flood alleviation policy. Due to the large differences between federal states in Germany (in relation to extent and conditions of public disaster relief), the study limited its focus to Saxony and Bavaria, two states that have experienced large-scale flooding in the last 10 years. In total, 11 persons were interviewed. ${ }^{2}$ The interview guide

\footnotetext{
${ }^{2}$ Interviewees were, in Germany, the German Insurance Association (GDV) (April 12, 2011, Berlin); AXA Insurance Germany (AXA) (May 6, 2011, telephone interview); Federal Agency for the Environment (UBA) (April 29, 2011, telephone interview); Saxon State Ministry of the Environment and Agriculture (SMUL) (April 13, 2011, Dresden); Bavarian State Ministry of the Environment and Public Health (STMUG) (April
} 
targeted themes regarding risks and insurability, relation to policy framework and regulation, the responsibility placed on different parties, actions taken to adapt to climate change risks and requirements for climate information services. All interviews were undertaken in the local language, transcribed verbatim and coded into the same four categories for which report material was relevant: The hierarchy and divided responsibility for natural hazards between state and insurers (e.g., responsibility placed on different parties, existing national or federal state adaption strategies); coordination with state adaptation activities and other stakeholders; adaptations taken in response to climate change (e.g., risk spreading and segregation, differentiated premiums, reducing loss by incentives or bundling flood insurance with other insurance); and adaptive capacitybuilding measures (e.g., underlying information such as flood maps). A focus in the study is placed on the interaction and distribution of responsibilities between public authorities and commercial insurers. An explicit focus on the broader organized public (e.g., flood victim organization) and individual level has been excluded; however, the paper does describe the potential impact on vulnerable populations.

\section{Results}

\subsection{The UK: private flood risk insurance in flux}

The UK insurance system is at present unique in that it is a fully privatized system where flood coverage is included as a standard feature of insurance (making the UK government at present not an insurer of last resort; Surminski 2009, 2010). However, although full insurance cover is required for mortgage to be granted, insurance coverage is not mandatory, leading to a higher level of uninsured clients among poor households (Botzen and van der Bergh 2008). This system has led to dissatisfaction from the industry on having to cover disproportionate risks in the face of large floods in 1998 and 2000 and is currently being renegotiated.

In the UK, adaptation is made relevant to insurance as "climate change ... [is] a pressure on the total amount of flood risk in the country" (DEFRA, interview I). Similarly, "flooding ... [is] the biggest adaptation risk that we face in the UK ... most of [what] I can talk about, in terms of what the insurance industry does, is flooding" (ABI, interview). However, insurance is included to only a limited extent in DEFRA's broader work on adaptation in the Adapting to Climate Change Programme (DEFRA, interview II). Instead the relation to insurance is dealt with in processes focused on the insurance industry as a part of more general flood risk issues (potentially given its state of flux).

Footnote 2 continued

20, 2011, Munich). In the UK: Climatewise (May 9, 2011, London); DEFRA, interview I, flood management (May 9, 2011, London); DEFRA, interview II, Adapting to Climate Change (ACC) Programme (May 9, 2011, London); ABI (May 12, 2011, London). In the Netherlands were the Dutch Insurers Association (Verbond van Verzekeraars; August 18, 2011, Zeist) and Eureko RE (August 18, 2011, Zeist) interviewed. In addition were in the UK insurance companies Aviva and Lloyds sought for interview, but declined referring to organizations already interviewed (Climatewise). In Germany, Allianz and Munich declined interviews. Both referred to the GDV as the more appropriate representative of the insurance industry. In the Netherlands was the financial markets authority and market behavior and stock exchange authority at the Ministry of Finance sought for interview, but both declined due to limited engagement in insurance and flood risk issues at present given the economic crisis. 
The UK flood insurance system developed after large floods in the 1950s as a "Gentlemen's Agreement' between Government and the insurance industry" (Huber 2004, 2), as a result of fear of nationalization and formal regulation restraining the insurance industry. The agreement ensured solidarity between home owners (equal risk spreading) and made flood insurance bundled with other insurance compulsory in that it had to be part of home insurance and was required to receive a mortgage (Huber 2004). However, "[i]n 1998 and 2000, two major floods challenged the economic basis of this setting" (Huber 2004, 2). As a result, since the year 2000 the Association of British Insurers (ABI) and the UK Government has had an agreement, the Statement of Principles on the Provision of Flood Insurance. Initially intended as a temporary measure, it has been revised over time and expired July 1, 2013. It obligates ABI members to make flood insurance "as widely available as possible" (ABI 2010,5) until this expiration date, "providing cover for the last decade to some otherwise uninsurable properties" (ibid.) although being able to cover this with relevant level of premiums.

The reasons why the agreement will not be renewed in its current form include that actors diverge on the extent to which the current system sufficiently encourages public investment in flood protection and that new insurers who do not have to maintain existing and potentially costly policies in flood risk areas can "cherry pick" lucrative areas in which they can offer lower premiums than others (DEFRA, interview I). Insurers also note that the present agreement includes "market distorting effects ... undermin[ing] incentives for homeowners to take steps to improve the flood resistance and resilience of their properties ... hinder[ing] the development of specialist flood insurance"(Surminski 2009, 31). Interviewees noted that as a result of this, "there's no true reflection of risk through price signals being issued to society and therefore people don't understand or feel that understanding of when they're at high risk" (ClimateWise, interview).

To preclude potential risks due to changes in the agreement, the government has published a document on flood resilient construction for new building works (cf. ABI 2009). ABI and the citizens' flood protection organization the National Flood Forum have published advice for customers (ABI and National Flood Forum, undated), advocating that customers should consider both options for flood resilience (acting to reduce damage that is caused when water gets into a property) and flood resistance (acting to reduce amount of water that can get into a property) (ABI and National Flood Forum, undated). The ABI has also produced guidance on insurance for new developments (ABI 2009) and has been developing guidance for local authorities on planning (available mid-2011) (ABI 2010). Among other things, the ABI recommends that "that developers follow National Planning Policy Statements, provide buyers with information on climate risks and how they are managed, [and] develop publicly available standards, or Kitemarks, that certify enhanced resilience to climate change impacts. Before buying a property in a new development, prospective owners should check the flood risk and obtain information on measures taken to reduce it" (ABI 2009). A collaborative industry initiative, ClimateWise, has also been formed to support insurance industry in incorporating the climate in investment strategies as well as to support consumer awareness on climate and to inform policy making (ClimateWise 2008a, b; ClimateWise, undated).

The situation after 2013 is currently under review within a multi-stakeholder process organized by DEFRA following its 2010 flood summit "to discuss the risk of flood insurance in flood risk management in the run-up to 2013 and beyond" (DEFRA 2011, 2). The process, the initial stages of which were reported in December 2011 (DEFRA 2011), includes participation by, among others, the Environment Agency, ABI, the British Insurance Brokers' Association BIBA, the Financial Services Authority FSA, the Treasury, communities and local 
government, and consumer groups such as the National Flood Forum (DEFRA 2011; DEFRA, interview I). Comprised by working groups on financial risks from flooding, data protection and transparency, and the property-level and customer interface, issues discussed in the process include a new model for funding flood risk management that includes both public and private contributions: a "shared responsibility ... between insurance industry, ... central and local government, and ... consumers" (ABI, interview). Criteria for a functioning system were defined through eight principles, discussed both by interviewees and in the December 2011 report (DEFRA 2011). These included that the selected model should be equitable, practical and deliverable, ensure wide availability of insurance, allow risk-based pricing, avoid distorting competition between insurance firms, encourage government and individuals to invest in flood risk management and be sustainable over a long period of time (DEFRA 2011; ABI, interview). The report reviews a number of different models to achieve this, including a pooling model currently investigated by Government, through which a subsidy for existing high-risk policy holders could be developed. In the opinion of one interviewee, the final choice of model "will be based on what the government feels like it can do in term of, you know, does it want to be an insurer of last resort? Those kinds of questions ... and what the insurance industry feels it can do. They'll be the drivers of what model we go for" (ABI, interview). "Is it right to subsidize people? What does 'affordable' mean? And there's not really a right answer and that's why it's a difficult process, because someone's got to answer the question and nobody wants to answer the question" (ABI, interview). During the continued activities in the working groups, decisions have focused on possibilities to price insurance according to risk while, through an internal industry levy system, maintaining possibilities to subsidize existing properties in risk areas (with work still ongoing in 2012) (DEFRA 2012; Benyon 2011).

Risk-based premiums thus constitute one major highlighted adaptation. However, the issue of making insurance continuously affordable even in flood plains with existing habitation while also providing incentives to avoid risk-is a major issue. "We've been doing a lot of work considering what kind of models you could use to ... subsidize insurance for people in high risk areas to make sure it remained affordable. ... various types of pooling arrangements where ... if you were above a certain threshold you'd get a subsidy, basically" (ABI, interview). In discussing whether government should act as insurer of last resort or not, one interviewee noted, "a lot of the options that we're looking at involve ... de-bundling flood risk, at least from, at least within the insurance company. It wouldn't necessarily have to be de-bundled in the consumer interface. You might ... still buy it as a joint policy, it's just once you get into the insurance company, they split it all out. You don't necessarily have to have that at the consumer side" (ABI, interview).

Obstacles to developing a well-adapted insurance scheme are to a large extent discussed by interviewees as well as in the report and updates, targeting much of the work in working groups on data provision as well as on property-level and customer interaction. On the government side, obstacles include recent budget cuts in governmental investments in flood defenses in relation to the economic crisis (ClimateWise, interview). Noting that the UK has relatively well-developed risk and cost assessments, as well as a relatively good integration of climate change issues in the planning system, the ABI representative noted that awareness-building and information sharing is important. A number of basic features for building adaptive capacity are seen as being in place. "In this country, the knowledge is there, the scientific knowledge is there ... we have one of the most advanced local to regional level mapping exercises" (ClimateWise, interview). ${ }^{3}$ The government has also committed itself to continued improvement of, among

\footnotetext{
${ }^{3}$ Interviewees also note that the EU Flood Directive may here further support data development, e.g., on surface water flood mapping (noted as relatively limited at the time, ABI interview) (DEFRA, interview I).
} 
other things, flood risk maps and flood alleviation schemes (Benyon 2011). As potential adaptations, the possibilities for more detailed comparison Web sites factoring in location and building date are under discussion. Other issues include faster Environment Agency updating of information on new flood defenses that have been constructed and which may impact premiums. The way that flood risk information is presented, for example on the Environmental Agency Web site, to make it more user-friendly to individual citizens for assessing flood risk is also being revised (DEFRA, interview I; DEFRA 2011). "A lot of what we're actually talking about is really quite ... practical things" (DEFRA, interview I).

On the industry side, obstacles to developing a well-adapted flood insurance system include problems of moving from non-specialized quotes on comparison Web sites to accurate single property-based risk assessments and costing, as well as trade-offs between equity and basing premiums more closely on actual risk (e.g., for people already living on flood plains) (ClimateWise, interview). "I think the big challenge there is that customers in general aren't rewarded for adopting resilient measures" (ClimateWise, interview). As a result, within the industry, and in relation to the ongoing process, "we're looking at various ...ways in which you could survey risk at a property level in a more standardized way. ... it's actually very important for the government that insurers take account with property-level flood risk, because that ties into the government's drive to get consumers to take their own responsibility" (ABI, interview). Practical problems would also include achieving agreement between insurers on requirements for information to assess property-level flood risk (so that the same property owner would not need to get several surveys done), information to property owners that may increase awareness and demand for surveying services, and also education to ensure that qualified surveyors undertake assessments (ABI, interview). Additional knowledge is also needed on how well different property-level improvements may decrease impact of flood risk. For instance: "a lot of resilience ... haven't really been tested in major floods. ... so it's quite hard to quantify [impact]. It's also quite hard for a consumer to know what is the appropriate type of resilience measures to put in place. ... Resilience has to be ... built-in with a sort of surveying approach" (ABI, interview).

As a result, insurance business models, customer education and perhaps even the idea of the type of service that insurance companies provide would need to change. "I think the industry is under no illusion that it's not starting or it's not currently in a place it wants to be, in terms of its relationship with customers" (ClimateWise, interview). "It's a very impersonal transaction as a customer ... it doesn't feel like you're buying into risk management services, which is how the insurance industry could be active and how a lot of its leaders would like to be positioned ... I think they are certainly trying to progress toward that" (ClimateWise, interview). All of these changes, such as discussions of development of incentives for resilience-developing measures and subsidies for groups in high-risk areas, will necessarily impact individual home owners and reflect, e.g., in positions of flood victim groups such as the National Flood Forum.

\subsection{Germany: a diversified market-based insurance system}

Germany has adopted a market-based natural hazard insurance system where private insurance companies provide coverage for natural hazards (as part of basic loss insurance)

\footnotetext{
${ }^{4}$ In addition, the Financial Services Authority (FSA) which is the regulatory agency for the UK insurance industry following surveys after two major flood events (2007 and 2009) noted that insurers do not use sufficiently clear and unambiguous language in their dealings with customers, and also that consequences of lapsing a policy are not sufficiently highlighted.
} 
as a supplement to building or content insurance forms (Schwarze and Wagner 2007; Thieken et al. 2006). The federal government has only limited legal competence regarding protection against natural hazards such as flooding. Water management and flood protection and prevention in Germany to a large extent fall within the jurisdiction of the individual federal states. Insurance against fire but not against other atmospheric or geological hazards is generally required by banks in return for granting a mortgage; however, the two most costly natural hazards in Germany are storms and floods (Munich 2011).

The institutional setting of Germany's market-based natural disaster insurance system reflects the countries federal system in a nutshell. Political responsibilities for water and flood policy are distributed between the federal government, federal states (the Länder) and local authorities. At present, there exists no federal legislation that stipulates under which circumstances and to what extent governmental support is granted to citizens or enterprises in case of a natural disaster. Amid the absence of overarching federal legislation, regulations on disaster aid and requirements for insurance coverage differ considerably between federal states, making governmental support strongly context dependent.

Coverage against floods and other natural hazards is provided in elementary loss insurance. Depending on the federal state and legal framework, market penetration of elementary loss insurance differs regionally with a national average of an estimated $30 \%$ (GDV, interview). For example, in the federal state of Baden-Württemberg which used to require comprehensive insurance against natural hazards by law until 1994, $95 \%$ of all buildings are covered by elementary loss insurance. In comparison, in the federal state of Bremen, only $11 \%$ have the same kind of insurance coverage due to the absence of a historic compulsory insurance and a higher degree of exposure to flood risks (GDV, interview; GDV 2013). Market penetration of elementary loss insurance above national average in the former East Germany, which can explained by the fact that after the German reunification many commercial insurers decided to continue the policies of the compulsory home insurance of the East German government, which included coverage against all known kinds of natural risks including flooding (Schwarze 2004a, b).

In 2002, Germany's highly diverse natural hazard insurance system came under scrutiny when a large flood struck the east of the country causing $€ 11.64$ billion in damage and 21 causalities (Thieken et al. 2006) (cf. Vulturius and Keskitalo 2013, in prep.). ${ }^{5}$ In response to the flood, the federal government provided financial support in the form of emergency funds and a reconstruction aid fund worth $€ 7.6$ billion in total, while insurance covered losses of $€ 1.8$ billion (Thieken et al. 2006). Most of these damages occurred in the federal state of Saxony, in the former East Germany which at least in part explains why the share of insurance claims was well above average. Between 40 and $80 \%$ of households affected by the flood in the area where covered by elementary loss insurance. Federal government disaster assistance in 2002 turned out to be more than six times higher than compared to earlier floods (Mechler and Weichselgartner 2003; Linneroth-Bayer et al. 2001), which led to speculations that financial support had been boosted in anticipation of upcoming national elections.

The unprecedented extent of damages and the apparent lack of disaster preparedness had two major implications for climate change adaptation policy and natural hazard insurance system in Germany. First, the flood in 2002 became seen among decision makers as a harbinger of climate change and spurred policymaking to address climate change impacts in Germany (cf. Vulturius and Keskitalo 2013, in prep.) (see Bundesregierung

5 This study does not review the financial and political impact of a flood of similar scale that occurred in June 2013. 
2008). Secondly, the indiscriminate manner in which governmental aid was allocated after 2002 sparked a debate about the role of state disaster relief and private natural hazard insurance.

This debate was launched in 2003 when a number of members of the Federal Parliament put forward a proposal for nationwide compulsory natural hazard insurance scheme (Schwarze and Wagner 2007). This proposal advocated for a redistribution of financial responsibilities for cost from natural hazard among governmental authorities, the insurance sector and individuals. It foresaw a compulsory multiple-risk insurance coverage against all natural hazards, including coverage of flood risks offered by private insurers based on risk-based premium setting (akin to the current voluntary system). State relief would be granted where total losses exceeded $€ 8$ billion. Proponents argued that this market-based compulsory natural hazard insurance system would unequivocally define financial liabilities of the insurance industry and the state, solve the demand problem of natural insurance and create a sufficient size effect for insurances to offer widespread and affordable coverage as well as incentivize individual precautionary measures through built-in risk-based premiums and deductibles. However, the idea of a compulsory natural hazard insurance system was ultimately rejected by committee of experts summoned by the Conference of German Finance Ministers (FMK) in 2004. In its final assessment, the committee cited lack of funding and legal reservations as reasons as to why it deemed a compulsory insurance system as neither politically nor economically feasible (Schwarze and Wagner 2007).

Representatives of the insurance industry interviewed for this study also strongly objected to the idea of a compulsory natural hazard insurance system. They argued that a mandatory system would discourage individual precautionary actions and would be met with high public disapproval because of contemporary low levels of risk awareness among citizens. Previous practices of granting state disaster relief also drew criticism from the insurance industry. The representative from GDV voiced the criticism that governmental assistance in 2002 had been granted to reconstruct areas known to be prone to recurring floods in the future instead of financing preventive measures. Previous research has shown that the German insurance industry suspects that state disaster aid is ill-informed and nontransparent and that it requires a more consistent, reliable and context-sensitive legal framework that would help to avoid rebuilding exposure and vulnerability of property and human life to natural hazards (Welp et al. 2010). Moreover, interviewees stressed that disaster aid paid to individuals and companies independent of prior actions could potentially discourage individual precaution and preparedness.

Consensus between insurers and legislators appears to be more likely on the importance of individual responsibility for flood protection and prevention. Ongoing discussions between the industry and governmental authorities reviewed for this study are pointing toward a solution that would disqualify citizens from state support if insurance coverage could have been obtained beforehand (already adopted in Bavaria, cf. StMF 06.09.2011). Similar legislation is currently being discussed in Saxony (SMUL, interview). All interviewees unanimously stated that they place greater responsibility on individual precaution than a decade ago. The representative of the UBA called this development a paradigm shift, stressing that flood protection and precaution are no longer the sole responsibility of the state but of the individual as well:

There is a general discussion about what role the state assumes and what role the citizen assumes. This is reflected in flood protection and flood precaution as well. The question is to what extent the state is covering all risks .... and to what extent citizens have their own responsibility. I recognize that this matter is changing, that 
citizens have their share in making themselves knowledgeable and adopting precautionary measures. This paradigm shift is reflected not just in this matter but how risks are handled in general (UBA, interview).

Arguments in favor of greater individual precaution and responsibility were echoed by the representatives of the insurance industry (cf. Welp et al. 2010). On the legislators' side, insurance companies recommended tax benefits for natural protection and precaution measurements and awareness campaigns as possible tools to encourage private adaptive actions (ibid.). However, a previous study on the impacts of the flood in 2002 on the insurance industry has shown that only a small minority of companies started to actively incentivize risk reduction measures among policy holders by rewarding voluntary flood mitigation measures (Thieken et al. 2006). Instead, some companies responded to the events in 2002 by withdrawing coverage in some of the areas affected (Schwarze and Wagner 2004a, b).

Coordination between the insurance industry and federal governmental agencies in regard to climate adaptation has so far been established as part of the consultation process for the drafting of the federal adaption action plan, which constitutes the first legal deliverable of the German strategy for adaptation to climate change (Bundesregierung 2011). Another platform of collaboration is represented in the Climate Change Finance Forum (Finanz Forum Klimawandel), which calls upon representatives of the German financial service industry and federal ministries that work together to establish a nationwide climate protection and adaptation strategy. Members, of whom two represent the insurance industry, have agreed to jointly intensify research on climate and weather information, market-focused information systems, development of analysis and evaluation methods, improved networking and best-practice evaluations. Communication and coordination between the insurance industry and the federal ministries in regard to research on climate change is partly led by the newly founded Climate Service Center (CSC), an element of the federal strategy on climate change supplying data regarding future climate change and its impacts (BMBF 2007). A research project on heavy rainfall patterns and frequencies conducted by the CSC and financed by the GDV is currently in its initial phase, ${ }^{6}$ aiming to assess how climate change may affect heavy rainfall patterns and expected damages. Potentially, results of this research could feed into the ZÜRS system, a GIS-based flood risk mapping software developed and administered by the GDV. The ZÜRS system assigns each individual piece of real estate to one of four flood risk categories and is widely used by insurers for risk assessment and premium calculations (GDV, interview). It also constitutes the only nationwide flood risk mapping inventory in Germany. Such systems could support further risk-based pricing, for instance "zoning as an instrument for price calculation ... For this purpose we need this seal of approval, given by a flood competence center, the CSC, or the federal government, which verifies that this zoning system ... provides a grade that one can accept as a basis for rating" (AXA, interview).

There is also evidence that collaboration between insurance companies and authorities on the regional and local scale is impacted by an uneven distribution of resources and political authority where flood-related policies are concerned. With reference to the federal system in Germany, all interviewees of political institutions placed the largest responsibility for flood protection on the federal states. Representatives of the insurance industry stated that data collection for flood risk analysis has been hampered by uneven technical

\footnotetext{
${ }^{6}$ Personal information, GDV, 30/05/2011.
} 
capacities among public water administrations, ambiguous distribution of water and flood management competence and widespread lack of awareness of climate risk among municipalities. In more general terms, risk awareness among federal states and their water authorities is split between those that have been affected by floods in the past and are actively collaborating with the insurance industry and those that are still reluctant to do so (GDV, interview).

\subsection{The Netherlands: public risk coverage}

In the Netherlands, private flood insurance was abolished after the great sea flood of 1953, which devastated large areas of the Zeeland province (Duiser 1982). Hence, in the period after 1953, the Dutch way of dealing with flooding was based on a probability approach, which made flood defense a common good that was taken care of by the state through dams, systems of canals and barriers. Today, however, climate change is increasing risks for sea level rise that may spill over or breach primary water barriers (Klijn et al. 2007). As a result of revised risks, the Calamities and Compensation Act (Wet Tegemoetkoming Schade bij rampen en zware ongevallen, in short: WTS), in force from 1998 (Botzen et al. 2010), provides legal arrangements for disaster loss compensation In practice, this means that in cases of loss as a result of disasters such as floods, the state aims to compensate the loss using public resources, which derive from tax income and state loans. The WTS also aims at highlighting the role of new private insurance arrangements (Botzen and van der Bergh 2008). As is elaborated in Sect. 4.3, such arrangements have yet to be developed in practice. Partly induced by climate change scenarios, the technical approach, based on dams and barriers, has also been shifting toward more spatial solutions such as the space for water program, based on the idea that less human control and more space for water dynamics in riverine and coastal areas can provide more safety as well as a growth in ecological and landscape quality (Smits et al. 2006; Van Stokkom et al. 2005; Wiering and Arts 2006).

In the Netherlands, as a country largely below sea level, the national government is responsible for the general policy on adaptation and water management. Provincial governments play a role in the design of water management strategies and are the main executives for implementation. The water boards have the responsibility of maintenance of the dykes, the management of water levels in canals and water quality, whereas the main rivers, waterways, large lakes and seas are under the responsibility of the national ministry. Municipalities manage the sewage systems (Web site "leven met water"). Water safety is thus a public responsibility in which insurers do not play a significant role.

In line with the Dutch public insurance system, a crucial part in Dutch catastrophe management was the disaster compensation act (Wet Tegemoetkoming Schade bij rampen en zware ongevallen, in short: WTS). The WTS, which came into effect in 1998, aims to compensate individuals who have suffered damage as a result of extensive disasters, including floods. The compensation is taken from existing tax income and state loans; there is no system of premiums or funds (Botzen and van den Bergh 2008). In the current agreement on water, the following strategy concerning flood risk and potential damage due to floods is used. Firstly, the state acknowledges that individuals have the duty to prevent and diminish potential damage. The government however has a so-called duty to care (Zorgplicht). The government has stated its intention to make flood damage insurable, and finally, the WTS functions as a final means to eventually compensate people for damage suffered (Nationaal Bestuursakkoord Water 2003). In practice, the current situation shows that insurance policies for households against water damage are integrated in general house 
insurance. These policies have excluded coverage for damage as a result of flooding. Insurance for damage due to extreme rainfall is now available for $40 \%$ of the insurance policies for households. Only $11 \%$ of these policies are also available for businesses (Kok and Lammers 1999). However, since 2004, harvest insurance against extreme rainfall has also been available, supported by the Dutch government by doubling the fund in case of damage, up to a maximum of $€ 50$ million.

Currently, the Dutch Cabinet considers a flood insurance fee for individual citizens too costly and in the current economic situation designates it as "undesirable" (website Verening voor Verzekeraars). The Dutch government installed a taskforce on flood management which has been assessing the Dutch safety situation and advising on which steps should be taken in case of flooding. This research culminated in a report in 2009 which mainly developed disaster scenarios, training and evacuation strategies. In this report, no direct mention is made of flood insurance as an adaptation strategy. In addition, the "Commission Veerman," which was established to assess current flood protection and define measures to improve safety, has denied a request from the water boards to set up a fund for flood damage and focused solely on a so-called delta fund, aimed at financing preventive measures such as reinforcement of existing dykes. However, proponents of insurance consider its role in contributing to financial structures for the existing safety and adaptation measures. This is defined as flood insurance based on the "rest-risk" (Aerts 2009). The insurance industry interviewees pointed out that there are several examples of flood hazards in which the state eventually did not or not fully cover the expenses of flood damage. "There are no clear criteria that describe what is covered and what is not, in how far the individual is responsible him- or herself and under which circumstances this is not the case" (Union of Insurers, interview).

Dutch insurance companies, represented in the union of insurers, have designed a proposal for a public-private insurance scheme concerning flood insurance. According to interviewees, individual flood insurance needs to be in cooperation with and enforced through the government, that is nationwide, for it to be viable. Those individuals living in higher parts of the country are not willing to pay for a risk they do not perceive, whereas the premiums for lower-lying areas would be too high if not shared with the rest of the country. "So the insurance business is trying to work with the government and would like to describe and assess the risks in different areas, differentiate premiums accordingly and make flood insurance a national obligation. For this we are dependent on the government" (Union of Insurers, interview).

However, the exact possibilities for such insurance arrangements-possible obligatory-as well as the specifications of differentiations in premiums have not yet been fully researched and calculated (see Aerts 2009; Aerts and Botzen 2011). While public-private interaction between the Dutch state and the insurance industry has been ongoing for years, in the last 2 years the discussion has been put on halt as the government has, so far, not been interested in develop these proposals further. Without a decision from the Dutch government that public-private cooperation will be developed, the insurance companies are reluctant to further develop such a product. "If we want to do this then a political decision to do it first has to be made. We are not investing in such a product if this choice has not been made" (Eureko RE, interview).

Insurers air the opinion that a public-private arrangement would oblige the state to pay in case of a great flood disaster in the near future, even though no build-up of insuring capital of the required magnitude has occurred; in the case of the WTS, it remains a political decision whether or not to fully compensate for damage. The proposal of private insurers is aimed at a public-private design in which ultimately the state remains the most 
important partner in insuring flood risks. In such a design, a clear limit to what damage insurers can compensate for is built in. However, in cases of small disasters, policy holders can rely on insurers to compensate them for the damage. This would, in the case of small disasters, create a certainty of compensation. Such a certainty is, according to insurers, not a given in the present situation.

Another argument for the insurance business to become part of the flood and disaster management in the Netherlands is, according the interviewees, the fact that risks and potential damage can be much better estimated in comparison to 50 years ago. While general knowledge and information that may support adaptive capacity-building exist (for instance, models that can predict specific water conditions related to river discharges), little information to build flood policy on exists, as flood damage in the Netherlands during the last 20 years has been limited due to the extensive dam and barrier system erected. However, in part due to the specific situation of the Netherlands in relation to flooding and water management, a multitude of parties (governmental, consultancy, universities) that have been involved in climate measurements, flood predictions and research on water management in relation to climatic changes, the insurance industry has all the knowledge it needs at its disposal. For instance, through participation by the insurance industry in the project "Veilig NL in Kaart," initiated by the national authority for water management and reported in 2006, models to calculate the probabilities of floods have been developed. With such information available the more pressing matter is "the difficulty ... in translat[ion] ... into insurance policy. It is more about how to insure the risks and how to keep it affordable, but another consideration is how to maintain enough public support for such a product" (Union of Insurers, interview). Insurers also agree that insurance may influence individual behavior to minimize risks, if such measures are within the range of capabilities of the individual. However, due to the current situation in the Netherlands, it seems that personal responsibility is difficult to define (Eureko RE, interview; Union of Insurers, interview).

Currently, the Dutch insurance association is exploring the possibilities of designing an insurance for flooding that incorporates only a minimal role or maybe even no role for the state. Ideas to cooperate with re-insurers and banks or through stock market mechanisms are currently being explored. Whether such options are viable is, at this early stage, very difficult to assess. Many individual insurance companies are reluctant to design insurance policies that are for the greater part or even fully private. Especially since the insecurities about flooding, flooding probabilities are very high. "The possible size of a disaster is unknown and there is a lot of uncertainty in the calculation of such an event. Therefore it is difficult to assess the role of the government and the role of insurance companies as well as the possibilities to come to an agreement" (Eureko RE, interview). Also, flood insurance in the Netherlands would only work if it was compulsory. With only a small number of policy holders, the premiums would be extremely high. Apart from that, in the current situation, an individual having a flood insurance policy would be denied, or partly denied, compensation from the government disaster relief fund. In other words, those with flood insurance would get less compensation from the state than those without such insurance. For these reasons, the insurance industry argues that coordination with the state in a public-private arrangement is needed. "You can't let the market deal with the enormous risks; you need the state. But if more and more people had flood insurance, maybe slowly the role of the state can become smaller. The big question is how to begin" (Union of Insurers, interview). In the case of the Netherlands, thus, the high risks have so far precluded private insurance options. While the debate on a cost-sharing approach in the Netherlands, may reflect concerns on how to manage Dutch flood protection in the future, it also reflects the insurance business's search for new market opportunities. However, in 
the current situation, a public-private arrangement in dealing with flood risks seems largely unviable.

\section{Discussion and conclusion}

In all the three cases, the boundary of public and private responsibilities for financial damages from flooding is in flux-or, at the least, under discussion, with regard to risk sharing between public administration and insurance industry. The UK provides perhaps the strongest example of this, given the clear deadline for agreement on a new definite system. In Germany although proposals for a more comprehensive change in regulating have been rejected (see also Thieken et al. 2006), private and public actors have started to change their policies to stimulate individual preventive action. The Netherlands provides to some extent an illustration of ongoing discussions on the public-private boundaries of responsibilities, but with no clear deadlines for agreements. In all cases, however, concerns over risks, either in relation to potential risk (the Netherlands) or in relation to the reoccurrence of events at the level of recent disturbances (the UK and Germany), have prompted re-assessments of current systems. While commercial insurance has not been a focal issue in adaptation policies in any of these countries, the potential of climate-related risks may come to play a large role-even if perceived in terms of risk for extreme events rather than necessarily in relation to climate change in general. Here we can see a change in the UK toward a system integrating private and public insurance authorities to some extent, with the private side pushing for a change in the current system. In Germany, the federal government has explored the option of compulsory natural hazard insurance, but both the federal government and the private insurance sector have come to the conclusion that this option is financially and legally untenable. In the Netherlands, finally, the public system, having responsibility for disaster relief but requiring a political decision in the case of each event, has been discussed by the private sector in particular, which is looking for the development of a partly layered insurance system (which Aerts and Botzen 2011, for instance, suggest could be remedied through development of short-term private flood insurance, a type of coverage that individuals may have an interest in even with existing state protection).

In all the cases, layered systems are emphasized as means to deal with increased risk, with existing events and potential risk being seen as reasons for reevaluation and change. What unites representatives of the private insurance industry interviewed for this study is a demand for long-term legislative framework that distinctively defines objectives and responsibilities of insurers and the different political authorities (national, region and municipal level) in climate change adaptation policies in order to have planning reliability in the future (cf. Welp et al. 2010). In Germany, regional authorities and commercial insurance companies are starting to more closely align their actions, shifting more responsibility for flood prevention to the individual policy holder. It remains to be seen if legislations recently enacted in Bavaria, which bars those individuals from governmental disaster assistance who could have purchased insurance coverage, becomes popular among legislators and the insurance industry and what the implications are for the availability and quality of insurance coverage and insurance payout speed. In the UK as in the Netherlands, debates are ongoing, and it has been noted that discussion "is in order about who should pay for the projected increase in flood losses, and how to establish an efficient and equitable flood loss compensation arrangement" (Aerts and Botzen 2011, 1060). Trade-offs will necessarily, as commercial insurance limits involvement in high-risk areas due to 
limited profitability, result in consequences at individual level, and in both changing insurance markets and changing compensation and subsidies: fundamentally, in all cases, a question of increasing integration between public administration and private insurance industry.

In the present situation, private insurance companies in all three countries have so far not actively incentivized risk reduction among customers by, for example, offering premium discounts in return for risk-reducing behavior. Evidence from this study suggests that the development of mechanisms that stimulate risk mitigation among policy holders are to a large extent emphasized. These include the development of a knowledge base (or an agreed knowledge base) on exposure, the development of insurance policies to calculate potential damage excess and value and the development of public-private boundaries of responsibility, in some cases including a "culture change" in the ways in which insurance industry may interact with its customers. All of these impact the distribution of risk between not only public administration and insurance industry, but also in effect distribute responsibility further toward the individual consumer or policy holder. These factors are discussed below.

Sufficient knowledge about probability of natural perturbations recurring and the potential damage associated with them has emerged from the material to enable adaptive capacity to be accommodated in natural hazard insurance systems (cf. Charpentier 2008). The existing repository of knowledge about flood risks was variable assessed by interviewees in the three cases studies. In the UK and Germany, interviewees remarked that existing small-scale mapping exercises of flood risk levels and potential damage provided for a substantial base for the adaption of premium systems; these were seen as matters that are to a large extent the province of government. On the other hand, interviewees in the Netherlands highlighted considerable uncertainties about potential damage excess and value. A stronger emphasis on individual responsibility for flood risk prevention was salient in interviewees' accounts in particular in the UK and Germany, which may indicate a change in the relationship between private insurance companies and their customers under conditions where higher damages occur due to climate change. This would in some part require a "culture change" in the way insurance currently interacts with its customers, a development discussed in this material, e.g., in the UK (cf. Mills 2003; LeBlanc and Linkin 2010), and would require higher awareness on part of the individual consumer as certain responsibilities are shifted toward individual level. Risk is thus defined as necessitating adaptations such as risk spreading and segregation (zoning in Germany or property-level assessment in the UK), and loss-reducing incentives and monitoring, such as resilience building and quotes on the property level rather than general quotes on insurance, as discussed in the UK (Botzen and van der Bergh 2008; Botzen et al. 2010) and Germany (GDV 2011; Thieken et al. 2006).

Organizational or more practical matters that would be needed to be solved to develop delineations suitable to all parties were thus a concern, in particular in the UK where demands for a re-establishment of public-private boundaries are immanent. These concerns indicated several practical adaptations that could support systems with potentially any private component, such as a revision of business models to provide and potentially create a demand for services that better support adaptation to flood risk (e.g., allowing property-level assessment and resilience-building measures), and ways in which government could intervene to ascertain the availability and affordability of insurance (e.g., through subsidies of insurance premiums) (Aakre and Rübbelke 2010). Standardized risk assessment guidelines and products in order to establish quality standards of risk consultancy that are recognizable for customers may also further support adaptation (Welp et al. 2010). Integration of more individualized and precautionary risk assessments, for instance related to precautionary and 
resilience-building measures on the particular property, has so far been limited and would need to be incentivized for such to be extended (despite a proven effectiveness in flooding situations; Kreibich et al. 2005; Botzen et al. 2009). Other literature suggests that also mitigation levels set through political measures would need to be determined, e.g., through stronger political frameworks, in order to develop a more secure political environment for insurance in the face of climate change (Charpentier 2008).

Acknowledgments This study gratefully acknowledges funding by Riksbankens Jubileumsfond and by the Department of Geography and Economic History, Umeå University. We are thankful to the anonymous reviewers for their valuable comments.

Open Access This article is distributed under the terms of the Creative Commons Attribution License which permits any use, distribution, and reproduction in any medium, provided the original author(s) and the source are credited.

\section{References}

Aakre S, Rübbelke DTG (2010) Objectives of public economic policy and the adaptation to climate change. J Environ Plan Manag 53(6):767-791

ABI (2009) Climate adaptation-guidance on insurance issues for new developments. ABI, London

ABI (2010) Fighting flood risk together. ABI, London

Aerts JCJH (2009) Onzekerheid verzekerd. Inaugural speech, Vrije Universiteit Amsterdam

Aerts JCJH, Botzen WJW (2011) Climate change impacts on pricing long-term flood insurance: a comprehensive study for the Netherlands. Glob Environ Change 21:1045-1060

Anderson DR (2000) Catastrophe insurance and compensation: remembering basic principles. CPCU J 53(Summer):76-89

Benyon R (2011) Progress towards developing future flood risk management arrangements. Written Ministerial Statement by Parliamentary Under-Secretary for Natural Environment and Fisheries (Richard Benyon) Dec 192011

BMBF, Bundesministerium für Bildung und Forschung (Federal Ministry for Education and Research) (2007) Die Hightech-Strategie zum Klimaschutz. Available online at http://www.bmbf.de/pub/ hightech_strategie_fuer_klimaschutz.pdf. Checked 08/12/2011

Botzen WJW, van den Bergh JCJM (2008) Verzekerd van of tegen klimaatverandering? Kwartaalschr Econ $2: 225-234$

Botzen WJW, van den Bergh JCJM (2012) Risk attitudes to low-probability climate change risks: WTP for flood insurance. J Econ Behav Organ 82(1):151-166

Botzen WJW, van der Bergh JCCM (2008) Insurance against climate change and flooding in the Netherlands: present, future and comparison with other countries. Risk Anal 28(2):413-426

Botzen WJW, Aerts JCJH, van den Bergh JCJM (2009) Willingness of homeowners to mitigate climate risk through insurance. Ecol Econ 68(8-9):2265-2277

Botzen WJW, van der Bergh JCJM, Bouwer LM (2010) Climate change and increased risk for the insurance sector: a global perspective and an assessment for the Netherlands. Nat Hazards 52(2010):577-598

Bundesregierung (Federal Government of Germany) (2008) German strategy for climate change. Adopted by the German federal cabinet on 17th December 2008

Bundesregierung (Federal Government of Germany) (2011) Aktionsplan Anpassung der Deutschen Anpassungsstrategie an den Klimawandel. Available online at http://www.bmu.de/files/pdfs/allgemein/ application/pdf/aktionsplan_anpassung_klimawandel_bf.pdf

Charpentier A (2008) Insurability of climate risks. Geneva Pap Risk Insur Issues Pract 33(1):91-109

ClimateWise (undated) Reducing the risk for tomorrow (information leaflet). ClimateWise

ClimateWise (2008a) ClimateWise public statement on the UNFCCC Copenhagen negotiations. Nov 2008

ClimateWise (2008b) ClimateWise one year review. Forum for the Future, London

DEFRA (2011) Flood risk and insurance: a roadmap to 2013 and beyond. Final report of the flood insurance working groups, Insurability of climate risks. Dec 2011

DEFRA (2012) Written ministerial statement: update on managing the impacts of flooding. The Secretary of State for Environment, Food and Rural Affairs (Caroline Spelman), Department of Environment, Food and Rural Affairs (DEFRA) July 112012 
Dlugolecki A (2008) Climate change and the insurance sector. Geneva Pap Risk Insur Issues Pract 33(1):71-90

Duiser JA (1982) Een verkennend onderzoek naar methoden ter bepaling van de inunadatieschade bij dijkdoorbraak, rapport 82-0644 van Industriele Veiligheid van MT-TNO, September 1982

EC, European Commission (2007) Directive 2007/60/EC of the European Parliament and of the Council of 23 October 2007 on the assessment and management of flood risks. Off J Eur Union L 288, pp 27-34. Available online at http://eur-lex.europa.eu/LexUriServ/LexUriServ.do?uri=OJ:L:2007:288:0027: 0034:EN:PDF. Checked on 7/01/2011

Feyen L, Watkiss P (2011) Technical policy briefing note 3. The Impacts and economic costs of river floods in Europe, and the costs and benefits of adaptation. Results from the EC RTD ClimateCost Project. In Watkiss P (ed) The ClimateCost Project. Final Report. Stockholm Environment Institute

FSA (2011) Climate change thematic review: flooding - do your customers know what they are covered for? A factsheet for general insurance providers. FSA, London. http://www.fsa.gov.uk/Pages/Library/ Other_publications/Miscellaneous/index.shtml. Accessed March 152011

GDV, German Insurance Association (Gesamtverband Deutscher Versicherer) (2011) Auswirkungen des Klimawandels auf die Schadensituation in der deutschen Versicherungswirtschaft. Kurzfassung Hochwasser. Available online at http://www.gdv.de/wp-content/uploads/2012/01/Klimakonferenz_ 2011_PIK_Studie_Hochwasser.pdf. Updated on 16/12/2011, checked on 7/02/2012

GDV, German Insurance Association (Gesamtverband Deutscher Versicherer) (2013) Elemtarschadenversicherung im Überblick. Available at http://www.gdv.de/wp-content/uploads/2013/08/GDVGrafik-Versicherungsdichte_Elementar_Ueberblick_2013.pdf. Checked on 18/08/2013

Herweijer Celine, Ranger Nicola, Ward Robert E T (2009a) Adaptation to climate change: threats and opportunities for the insurance industry. Geneva Pap Risk Insur Issues Pract 34(3):360-380

Herweijer C, Ranger N, Ward RET (2009b) Adaptation to climate change: threats and opportunities for the insurance industry. Geneva Pap Risk Insur Issues Pract 34(3):360-380

Huber M (2004) Reforming the UK flood insurance regime: The breakdown of a gentlemen's agreement. Discussion paper no. 18, ESRC Centre for Analysis of Risk and Regulation, London

IPCC Intergovernmental Panel on Climate Change (2007) Climate change 2007: impacts, adaptation and vulnerability. Cambridge University Press, Cambridge

Keskitalo ECH (2010) Climate change adaptation in the UK: England and South-East England. In: Keskitalo $\mathrm{ECH}$ (ed) The development of adaptation policy and practice in Europe: multi-level governance of climate change. Springer, Hanover

Klijn F, Baan P, De Bruijn KM, Kwadijk J, van Buren R (2007) Nederland Later en Water: Ontwikkeling overstromingsrisico's in Nederland. WLI Delft Hydraulics Q4290.00, Delft, Nederland

Kok M, Lammers IBM (1999) Onderzoek waterschade ten gevolge van neerslag. HKV lijn in Water, October 1999

Kreibich H, Thieken AH, Petrow T, Müller M, Merz B (2005) Flood loss reduction of private households due to building precautionary measures-lessons learned from the Elbe flood in August 2002. Nat Hazards Earth Syst Sci 5(1):117-126

Kunreuther HC (2006) Has the time come for comprehensive natural disaster insurance. In: Daniels RJ, Kettl DF, Kunreuther H (eds) On risk and disaster: lessons from Hurricane Katrina. University of Pennsylvania Press, Philadelphia

LeBlanc A, Linkin M (2010) Chapter 6: insurance industry. Ann N Y Acad Sci 1196:113-126 (2010, New York City Panel on Climate Change 2010 Report)

Linneroth-Bayer J, Quijano-Evans S, Löfstedt R, Elahi S (2001) The uninsured elements of natural catastrophic losses. Final report submitted in fulfillment of grant from Tsunami fund UK, Laxenburg

F\&C Management (2007) In the front line: the insurance industry's response to climate change. F\&C Investments

Maynard T (2008) Climate change: impacts on insurers and how they can help with adaptation and mitigation. Geneva Pap Risk Insur Issues Pract 33(1):140-146

Mechler R, Weichselgartner J (2003) Disaster loss financing in Germany-the case of the Elbe river floods 2002. Laxenburg (Interim Report IR-03-021)

Mills E (2003) Climate change, insurance and the buildings sector: technological synergisms between adaptation and mitigation. Build Res Inf 31(3-4):257-277

Mills E (2005) Insurance in a climate of change. Science 309(5737):1040-1044

Mills E (2009) A global review of insurance industry responses to climate change. Geneva Pap Risk Insur Issues Pract 34(3):323-359

Munich RE (1973) Hochwasser, Ueberschwemmung. Muenchener Rueckversicherungsgesellschaft, Munich

Munich RE (2011) NATCatService BRD 1970-2010 EURO Deutsch. Available online at http://www.ergo. com/de/Presse/Overview/Pressemappen/Wetterereignisse/ /media/ERGOcom/PDF/Praesentationen/ 
2011/201101-Naturkatastrophen-Trends-Deutschland.ashx. Updated on 22/02/2011, checked on 2/06/ 2011

Nationaal Bestuursakkoord Water http://www.helpdeskwater.nl/publish/pages/473/nationaal_bestuursakkoord_ water.pdf

Petrow T, Thieken AH, Kreibich H, Merz B, Bahlburg CH (2006) Improvements on flood alleviation in Germany: lessons Learned from the Elbe flood in August 2002. Environ Manage 38(5):717-732

Schwarze R, Wagner GG (2004a) In the aftermath of Dresden: new direction in German flood insurance. Geneva Pap Risk Insur Issues Pract 29(2):154-168

Schwarze R, Wagner GG (2004b) In the aftermath of Dresden: new direction in German flood insurance. Geneva Pap Risk Insur Issues Pract 29(2):154-168

Schwarze R, Wagner GG (2007) The political economy of natural disaster insurance: lessons from the failure of a proposed compulsory insurance scheme in Germany. Eur Environ 17(6):403-415

Schwarze R, Schwindt M, Weck-Hannemann H, Raschky P, Zahn F, Wagner GG (2011) Natural hazard insurance in Europe: tailored responses to climate change are needed. Environ Policy Gov 21(1):14-30

Smit B, Wandel J (2006) Adaptation, adaptive capacity and vulnerability. Glob Environ Change 16:282-292

Smits AJM, Nienhuis PH, Saeijs HLF (2006) Changing estuaries, changing views. Hydrobiologia 565:339-355

StMF, Bayerisches Staatsministerium der Finanzen (Bavarian State Ministry of Finance) (6/09/2011) Richtlinien über einen Härtefonds zur Gewährung finanzieller Hilfen bei Notständen durch Elementarereignisse (Härtefondsrichtlinien - HFR). 6321-F. Amtsbl Bayer Staatsminist 66 (9):310-338

Surminski S (2009) Risk prevention and flood insurance in the UK: ensuring availability in the face of risking climate risks. Climate change: global risks, challenges and decisions. IOP Conf Ser Earth Environ Sci 6:422006

Surminski S (2010) Adapting to the extreme weather impacts of climate change-how can the insurance industry help? A ClimateWise study report for those interested in reducing risk. ClimateWise, London

Thieken AH, Petrow T, Kreibich H, Merz B (2006) Insurability and mitigation of flood losses in private households in Germany. Risk Anal 26(2):383-395

UNEP (2009) The global state of sustainable insurance. Understanding and integrating environmental, social and governance factors in insurance. Available online at http://www.unepfi.org/fileadmin/documents/ global-state-of-sustainable-insurance_01.pdf. Updated on 29/01/2010, checked on 24/07/2012

Van Stokkom HTC, Smits AJM, Leuven RSEW (2005) Flood defense in the Netherlands: a new era, a new approach. Water Int 30:76-87

Vetters N, Prettenthaler F (2003) Extreme Wetterereignisse: Nationale Risikotransfersysteme im Vergleich. Institute of National Economy, University of Graz

von Ungern-Sternberg T (2004) Efficient monopolies - the limits of competition in the European property insurance market. Oxford University Press, Oxford

Vulturius G, Keskitalo ECH (2013) Adaptive capacity building in the Region of Dresden? Responses to the 2002 flood in planning and policy. In: Keskitalo ECH (ed) Climate change and flood risk management: adaptation and extreme events at the local level. Edward Elgar Press (in preparation)

Welp M, Lotz W, Gebauer J, Wurbs S (2010) Ergebnisse des Stakeholderdialogs zu Chancen und Risiken des Klimawandels - Versicherungen -. UBAKomPass (Kompetenzzentrum Klimafolgen und Anpassung im Umweltbundesamt). Available online http://www.anpassung.net/nn_700470/DE/ Anpassungsstrategie/Veranstaltungen/Dialoge_20zur_20Klimaanpassung/1006_20Versicherungen/ Ergebnisspapier,templateId=raw,property=publicationFile.pdf/Ergebnisspapier.pdf. Updated on 31/08/ 2010, checked on 21/03/2011

Wiering MA, Arts BJM (2006) Discursive shifts in Dutch river management: 'deep' institutional change or adaptation strategy? Hydrobiologia 565:317-325

Wits JW (2011) Kabinet ziet af van overstromingspolis. http://www.verzekeraars.nl/sitewide/general/ nieuws.aspx?action=view \&nieuwsid=722 